\title{
The Characters of Special Region According to The 1945 Constitution of Republic of Indonesia
}

\author{
Asep Bambang Hermanto*, Anggara Suwahju** \\ DOI: https://doi.org/10.22304/pjih.v6n2.a6
}

Submitted: June 28, 2019 | Accepted: Sept 7, 2019

\begin{abstract}
The Republic of Indonesia, based on the 1945 Constitution, the second Amendment, recognizes the existence of a Special Region and its distinctive governance. Article 18B, Paragraph (1), of the 1945 Constitution reads, "The State shall recognize and respect entities of regional administration that possess a specificity or a distinctiveness that are to be regulated by law". Previously, the governance of special region was also regulated in the first version of the 1945 Constitution that was stipulated on August 18, 1945. In addition, it is contained in other constitutions that were formerly effective in Indonesia: the 1949 Constitution of the Republic of the United States of Indonesia, and the 1950 UUDS. The clearest arrangements regarding the status of special region were covered by the 1950 UUDS, whereas the 1945 and the 1949 Constitutions do not provide detailed description of special regional government units. This triggers some fundamental questions related to the substance of special region. This study reveals several facts related to the existence and administration of government in special regions. Among other things, the current arrangement does not open up the possibility of forming new special regions and the administration of special region only exists at the provincial level.
\end{abstract}

Keywords: constitution, special region, unitary state

\section{Substansi Daerah Istimewa Menurut Undang-Undang Dasar Negara Republik Indonesia 1945}

\begin{abstract}
Abstrak
Negara Republik Indonesia, berdasarkan Undang-Undang Dasar 1945, Amandemen ke-2, mengakui eksistensi Pemerintahan Daerah yang bersifat Istimewa. Pasal 18B, Ayat (1), UUD 1945 berbunyi, "Negara mengakui dan menghormati satuan-satuan pemerintahan daerah yang bersifat khusus atau bersifat istimewa yang diatur dengan Undang-undang". Sebelumnya, pemerintahan daerah yang bersifat istimewa juga pernah diatur dalam UUD 1945 versi pertama yang ditetapkan 18 Agustus 1945, Konstitusi RIS 1949, dan UUDS 1950. Pengaturan yang jelas mengenai status daerah istimewa tertuang dalam UUDS 1950, sedangkan UUD 1945 dan Konstitusi RIS 1949 tidak memberikan penjelasan rinci mengenai
\end{abstract}

PADJADJARAN Journal of Law Volume 6 Number 2 Year 2019 [ISSN 2460-1543] [e-ISSN 2442-9325]

* A Lecturer of Contitutional Law, University of Pancasila, Jl. Srengseng Sawah, Jagakarsa, Jakarta Selatan, abambang0706@gmail.com, S.H. (Universitas Padjadjaran), M.H. (Universitas Padjadjaran), and Dr. (Universitas Padjadjaran).

** Executive Director of Institute for Criminal Justice Reform, Jl Attahiriyah No 29, Pasar Minggu, Jakarta Selatan, anggara@icjr.or.id, S.H. (Universitas Padjadjaran), M.H. (Universitas Pancasila). 
satuan pemerintahan daerah yang bersifat istimewa. Hal tersebut memicu beberapa pertanyaan mendasar terkait makna daerah istimewa. Kajian ini menemukan beberapa fakta terkait eksistensi dan penyelenggaraan pemerintahan di daerah-daerah istimewa. Di antaranya, pengaturan yang ada saat ini tidak membuka kemungkinan pembentukan daerah-daerah istimewa yang baru dan pemerintahan daerah istimewa hanya ada di tingkat provinsi saja.

Kata Kunci: daerah istimewa, negara kesatuan, konstitusi

\section{A. Introduction}

The people of Indonesian have a long history of government systems since the era of the royal government system to the current implementation of the republic system. Various rural areas in Indonesia also recognize similar-to-republic's concepts. For example, Bagir Manan suggests that there is a village government unit in South Sumatra called marga. Marga is conceptually a republic because its leader, pasirah, comes from and is directly elected by the community. Pasirah is not hereditary as the royal political tradition. Such practices have actually been known for a long time. They have existed in the practice of people governance since before the presence of Dutch colonialism in Indonesia.

The discussion over the concepts of republic or kingdom had begun before the formulation of the 1945 Constitution. Once, some political figures wanted a royal system. Different political desires were ended by a vote, which eventually resulted the republic. $^{1}$ It is then contained in Article 1, Paragraph (1), of the 1945 Constitution, which reads "The State of Indonesia shall be a unitary state, with the form of a Republic". ${ }^{2}$ Theoretically, a unitary state, according to Kalijarvi, is a state where all power is concentrated in one or several central organs without any division of power between central and regional governing bodies. In other words, a unitary state is a state with a centralized power. ${ }^{3}$ In a unitary state, the source of power is the central government, which then transfers its power to regional governments. In essential, central government is the true owner of power. ${ }^{4}$ Therefore, different with the power or authority of regional state in a federation state, the power of regional government in a unitary state is not fundamental

\footnotetext{
Jimly Asshiddiqie, Pokok Pokok Hukum Tata Negara Indonesia Pasca Reformasi, $2^{\text {nd }}$ edition, Jakarta: BIP Gramedia, 2008, pp. 280-281

4 Abdul Gaffar Karim, et.al., Kompleksitas Persoalan Otonomi Daerah di Indonesia, Yogyakarta: Jurusan IImu Pemerintahan FISIPOL UGM kerjasama dengan Pustaka Pelajar, 2006, p. 61.
} 
power. Law confers the power. In this case, parliament can abolish some or all authorities of regional government. ${ }^{5}$

The implementation of regional government has experienced dynamics in the course of the development of the Indonesian constitution. Article 18 of the 1945 Constitution of the Republic of Indonesia (Before Amendment) reads, "The division of Indonesian regions into large and small regions, with the form of government structure, is determined by law, with regard to and observance of the state's basis, and the right of origin in special regions". Referring to the original intent ${ }^{6}$, special regions are limited to areas called swapraja or zelfbesturende landschappen (during the Dutch East Indies government). However, the elucidation of Article 18 of the 1945 Constitution mentions the rights of origin in special regions, which are regions that have original composition, the zelfbesturende landschappen and volksgemeenschappen. It expands the coverage of Article 18 but, in reality, villages and volsgemeenschappen is never considered special region. ${ }^{7}$ The definition of special region is reviewed in the form of zelfbesturende landschappen. ${ }^{8}$

After the Second amendment of the 1945 Constitution on August 18, 2000, the idea of special autonomy was adopted in Article $18 \mathrm{~B}$, Paragraph (1). Special autonomy means that some parts of state is given the authority to regulate its own affairs in a number of ways by passing legislation without being followed by the formation of a new state building. ${ }^{9}$ This type of autonomy, according to Cassese, is known as internal self-determination. He argues that ${ }^{10}$ "Internal self-determination means the right to authentic self-government, that is, the right for a people really and freely to choose its own political and economic regime".

Some concepts of special autonomy in the form of internal self-determination that can be identified in legal construction are ${ }^{11}$

1. as a right to act upon one's own discretion in certain matters;

2. as a synonym of independence;

3. as a synonym of decentralization; and

4. as exclusive powers of legislation, administration, and adjudication in specific areas of an autonomous entity.

In line with the view, special autonomy can be interpreted as an autonomy that is obtained by a region to have self-governing body. The self-governing body is

\footnotetext{
C.F. Strong, Konstitusi-Konstitusi Politik Modern: Studi Perbandingan Tentang Sejarah dan Bentuk, Translated by Derta Sri Widowatie, Bandung: Nusamedia, 2018, p. 113.

6 The Liang Gie, Pertumbuhan Pemerintahan Daerah di Negara Republik Indonesia Jilid I, $2^{\text {nd }}$ edition, Yogyakarta: Liberty, 1993, p. 46.

$7 \quad$ lbid.

8 Ibid.

9 Hans-Joachim Heintze, On the Legal Understanding of Autonomy, in Markku Suksi, Autonomy: Application and Implication, Finland: Kluwer Law International, 1997, p. 7.

10 Antonio Cassese, Self Determination of Peoples: A Legal reappraisal, Cambridge: Cambridge University Press, 1995, p. 101.

11 Hans-Joachim Heintze, op.cit.
} 
different from other regions as a recognition of partial independence from the influence of the central government. It is determined through the level of autonomy in the process of political decision-making. ${ }^{12}$ In some cases, special autonomy arrangement is in response to national diversity, as either demands for autonomy from minority groups or when an independent entity receives selfgovernment status as a "reward" for joining an existing state. ${ }^{13}$ According to Hannikainen, some of the important authorities in special autonomy are as follows. ${ }^{14}$

1. The status of autonomous region must be determined by constitution or law that is above the statutory provisions in a country. It can also be based on an agreement between the central government and the people in the area.

2. Autonomous region must have a parliament, which is democratically elected by the people of the region, and has some independent legislative authority.

3. There are exclusive authorities in certain fields such as education and culture, language policies, social affairs, agrarian affairs, etc.

4. Autonomous regions have the possibility to become parties to the policy making process at the national level.

5. Local justice becomes part of autonomy and enjoys independence from executive and legislative powers.

6. The authority in taxation guarantees a strong foundation for economic development.

7. Autonomous region has right to cooperate with other regions or communities in neighboring countries, especially in the economic and cultural fields.

Within the framework of special autonomy, the Second Amendment to the 1945 Constitution contains Article 18 B paragraph (1).

"The State shall recognize and respect entities of regional administration that possess a specificity or a distinctiveness that are to be regulated by law."

In contrast to the previous 1945 Constitution, Article 18B, Paragraph (1) of the second amendment regulates two types of special autonomous regions: special autonomies for specific regions and special regions. However, the provision does

12 Marc Weller and Katherine Nobbs, Asymmetric Autonomy and the Settlement of Ethnic Conflics, Pennsylvania: University of Pennsylvania Press, 2010, p. 4.

13 John Mcgarry, "Asymmetry in Federations, Federacies and Unitary States", Ethnopolitics, Vol. 6, No. 1, 2007, p. 1.

14 Laura Hannikainen, Self Determination and Autonomy in International Law, in Markku Suksi (Ed.), Autonomy: Appication..., op.cit., p. 90. 
not detail of both types of regions and the indicators to determine status of an area. Furthermore, the 1945 Constitution also does not specify the specific level of government in which an area has the right to hold a special regional status.

\section{A. The Meaning of Special Regional Government}

To find the meaning of special regions in the Indonesian constitution and the Indonesian governance system, historical approach must be used to understand the institutions of the Special Regions according to Article 18B, Paragraph (1), of the 1945 Constitution. The legal history enables us to explore various aspects of Indonesian law in the past. Subsequently, it provides us assistance to understand rules and legal institutions that exist today. ${ }^{15}$

In the history of Indonesian administration, the status of special autonomy is not a new idea. The concept of special regions in Indonesia has its roots in the presence of Vereenigde Oostindische Compagnie (VOC) in the archipelago. During the era of VOC, independent kingdoms were still found in the archipelago. However, the VOC combined military and trade pressure to force native leaders to make agreements with them. Therefore, the kingdoms served under the VOC and henceforth became as vassal states ${ }^{16}$ of the Dutch. ${ }^{17}$

Therefore, although the Dutch East Indies had a united pattern, in 1854, the division of territorial power in the Dutch East Indies consisted of: ${ }^{18}$

1. directly controlled areas (Direct Best Gebied, Gouvernmentsgebeid);

2. local kingdoms that were integrated into the Dutch East Indies territory based on political contracts between the Governor General and the kings and the areas were not directly controlled (Indirect Bestuurd Gebied, Gebied met zelfbesturende Landschappen, Landschapbied); and

3. kingdoms or areas outside the control of the kingdoms, called "Affected Area", which means the sovereignty of the Dutch Crown is recognized in international relations based on international treaties.

In general, during the era of the Dutch East Indies, the territory was divided into (1) the territory of governors, which that is directly governed by the governor's officials, and (2) the Swapraja Region (Zelf besturende Landschappen), which is governed by native rulers as outlined in the statement. Even though the swapraja area has the authority to organize its own governance and to manage its own

\footnotetext{
Soejono Soekanto, Pengantar Sejarah Hukum, Bandung: Alumni, 1986, p. 9.

16 Vassal state, according to Merriam Websiter Dictionary is "a state with varying degrees of independence in its internal affairs but dominated by another state in its foreign affairs and potentially wholly subject to the dominating state". See Meriam-Webster, "Vassal State", https://www.merriamwebster.com/dictionary/vassal\%20state, accessed on May 2019.

17 David Henley, "Nationalism and Regionalism in Colonial Indonesia: The Case of Minahasa", JSTOR, No. 55, 1993, p. 93, https://www.jstor.org/stable/3351088, accessed on May 2019.

18 J.H.A Logemann, Het Staatsrecht van Indonesie, Yogyakarta: Badan Penerbit Gadjah Mada, p. 20.
} 
household, the leaders must make a statement, which basically confirms that they. ${ }^{19}$

1. recognize that the highest authority les on the hand of the Dutch crown;

2. obey all rules and orders from the crown government;

3. will not make agreements with foreign powers or countries; and

4. giving full authority to the Governor-General of the Dutch East Indies to participate in the swapraja's internal affairs.

During the era, the position of the swapraja regions was regulated in Article 21, Paragraph (2) of IS. A swapraja area was an autonomous region of the Dutch Indies government. Then, volksgemeenschappen is a village, a colony, a hamlet, a clan, etc. Dutch East Indies legislation also regulates volksgemeenschappen in terms of inlandsche gemeenten. ${ }^{20}$ The position of swapraja in the Dutch Indies constitutional system is regulated in Article 21, Paragraph (2), of the Nederlandsch-Indische Staatsregeling. It states that swapraja region is self-governing regions. ${ }^{21}$ In 1919 , the Ordonantie Zelfbestuurregelen was established, which took effect on April 1, 1920. It regulates the basic principles as follows: ${ }^{22}$

1. The internal governance structure of swapraja in general remained based on traditional customs.

2. The full authority of the Dutch Indies Government in the swapraja area only applies to the citizens of the Governorate. The swapraja citizens were under the autonomous authority of the swapraja for specific matters.

3. Autonomous power of swapraja includes the right to regulate, to administer (including the police), and to try legal disputes in all fields that are not explicitly excluded.

This Ordinance was then renewed and replaced by the 1927 Ordinance (Ind. Stbl 1927 Number 25). The Zelfbestuurregelen Ordinance 1938 (Ind. Stbl. 1938 Number 529) subsequently replaced it, which took effect on January $1,1939 .{ }^{23}$ The Ordinance contains 22 articles along with explanations and appendices governing the meaning of the Government of the Kingdom, the region, the composition of the government, the income, the authority of the royal government, the court, the police, land, forest, mining, tax, and the cooperation among the government of the

\footnotetext{
19 Bayu Surianingrat, Sejarah Pemerintahan di Indonesia: Babak Hindia Belanda dan Jepang, Jakarta: Dewaruci Press, 1981, p. 34.

20 Lukman Hakim, Filosofi Kewenangan Organ Lembaga Daerah: Perspektif Teori Otonomi \& Penyelenggaraan Pemerintah Negara Hukum dan Kesatuan, Malang: Setara Press, 2012, pp. 134-135.

$21 \quad$ Ibid, p. 134.

$22 \quad$ Ibid p. 59.

23 Ma'loemat Directeur Binnenlandsch Bestuur, October 5, 1938.
} 
kingdoms. ${ }^{24}$ In swapraja region, a swapraja court was established. Kings, Sultans, and the principals still held judicial authority and that power applied to the citizens of swapraja regions. ${ }^{25}$

During the Japanese occupation, Japan did not change the central and the local governments of the Dutch East Indies. However, the position of Governor General was abolished, while Raad van Indie and Volksraad were frozen. In addition, government organizations of regions, autonomous regions, and the local parliaments were frozen. However, the Japanese occupation government did not change Swapraja government organization and the customary legal alliance. ${ }^{26}$ Even, king gets an honorary military rank. ${ }^{27}$ The area was called Kooti and the kings were called Koo. They were reappointed by oath and inauguration to break off relations with the Kingdom of the Netherlands. Koo's position at this time was considered as part of the family members of the King of Japan. ${ }^{28}$

In the process towards independence of newly Indonesian state, Soepomo, together with Soebardjo and Maramis, drafted the Regulation of the Provisional Government of Indonesia. In the draft, the idea of special autonomy has emerged for certain regions (swapraja regions). In Article 16, the draft reads as follows. ${ }^{29}$

"Negeri-negeri yang mempunyai raja asli sendiri, tetap berdiri sebagai daerah-daerah, yang istimewa memegang kekuasaan sendiri di Indonesia. Perjanjian politik yang ada yaitu Korte Verklaring (Keterangan Singkat) dan Zelfbestuursregelen 1938 (Peraturanperaturan dari 1938 buat Kerajaan-kerajaan aseli) dan aturan-aturan sebagai akibat dari semuanya itu, berjalan terus, tetapi dengan perubahan ini, bahwa Pemerintah Indonesia yang sementara mengambil kedudukannya Pemerintah Hindia Belanda yang dulu dan Kepala Negeri yang sementara mengganti tempatnya Gubernur Jenderal yang dulu. Raja-raja aseli itu akan memberikan sumpah kesetiaan menurut pemelukan agamanya masing-masing kepada Kepala Negeri Indonesia dan Susunan Asia baru untuk bekerja dan kemakmuran bersama."

In the BPUPKI (Badan Penyelidik Usaha-usaha Persiapan Kemerdekaan IndonesiaInvestigating Committee for Preparatory Work for Independence), the idea of a

\footnotetext{
24 Algemeen Regering-Commissariaat voor Borneo en de Grote Oost, Zelfbestuuregelen 1938 Met Toelichting.

25 R. Tresna, Peradilan di Indonesia Dari Abad ke Abad, Jakarta: Pradnya Paramita, 1978, pp. 74-84; J.H.A Logemann, op.cit., p. 18.; R Soepomo, Sistem Hukum di Indonesia Sebelum Perang Dunia II, Jakarta: Pradnya Paramita, 1991, pp. 81-92.

26 G.J. Wolhoff, Pengantar Ilmu Hukum Tata Negara Republik Indonesia, Jakarta: Timun Mas, 1960, p. 73; Steven Glen Farram, "From Timor Koepang to Timor NTT: A Political History of West Timor, 1901-1967", A thesis for the degree of Doctor of Philosophy of the Northern Territory University, p. 10 - 11, https://espace.cdu.edu.au/eserv/cdu:6450/Thesis_CDU_6450_Farram_S.pdf, accessed on May 2019, p. 198.

27 Steven Glen Farram, ibid., p. 199.

28 The Liang Gie, op.cit., p. 28.

29 The Liang Gie, op.cit., p. 36.
} 
unitary state was crystallized and one of its advocates was Soepomo. Soepomo emphasized that the State of Indonesia rejects all understanding of federalism, which consequently is that Indonesia is a unitary state. He also stressed that the Indonesian State was run on decentralization or deconcentration, which is not a part of federalism. ${ }^{30}$ Muhammad Yamin also affirmed his stand, which favored unitarism. However, his views lied on conditions of Indonesia as a union state. ${ }^{31}$

Although this understanding of unitaryism is also strongly illustrated in Article 1 paragraph (1) of the 1945 Constitution, the founders of Indonesia have not forgotten the importance of implementing decentralization in the administration of government. Muhammad Yamin conveyed the idea about middle or local governments ${ }^{32}$ and asked questions about regional governments that were uniform in nature. ${ }^{33} \mathrm{He}$ also stressed the importance of breaking power both in the form of deconcentration or decentralization, which, according to him, could be done in the form of a Unitary State ${ }^{34}$ based on justice and wisdom. Article 18 of the 1945 Constitution regulates the position of the special regions. ${ }^{35}$

Elucidation of Article 18 of the 1945 Constitution of the Republic of Indonesia affirms as follows.

"In the territory of the State of Indonesia, there are approximately 250 zelfbesturende landchappen and volksgemeenschappen, such as desa in Java and Bali, nigari in Minangkabau, dusun and marga in Palembang, and so on. These regions have an original arrangement and can therefore be considered as special regions. The Republic of Indonesia respects the position of these special regions and all state regulations regarding these regions will commemorate the rights of the origin of these regions."

The Special Region in the Elucidation of Article 18 of the 1945 Constitution refers to zelfbesturende landchappen and volksgemeenschappen. Essentially, since the beginning of the BPUPKI, the special area mentioned by Article 18 of the 1945 Constitution was referred to the position of the swapraja areas, which were known during the Dutch East Indies as Zelbesturende Landschappen and during the

\footnotetext{
30 Saafroedin Bahar, et.al., Risalah Sidang Badan Penyelidik Usaha - usaha Persiapan Kemerdekaan Indonesia (BPUPKI) - Panitia Persiapan Kemerdekaan Indonesia (PPKI) 29 Mei 1945-19 Agustus 1945, Jakarta: Sekretariat Negara Republik Indonesia, 1992, pp. 17 -18.

31 Ibid, pp. $154-156$.

Ibid, p. 150.

lbid.

Ibid, p. 155.

Ibid, p. 157.
} 
Japanese occupation known as Kooti. At the beginning of the reign of the Japanese occupation government in 1942, there were to 278 autonomous regions. ${ }^{36}$

During the ratification of the 1945 Constitution by the PPKI on August 18, 1945, Soepomo explained the purpose of the provisions of Article 18 of the 1945 Constitution. ${ }^{37} \mathrm{He}$ mentioned that there had already special regions, kootis and sultanates, with their original compositions, remained and were respected. However, they must be viewed as regions, not the states. There must be no misunderstanding in respecting the existence of Zelfbesturende Landschappen region. They were not a state since there is only one state. Therefore, Zelfbesturende Landschappen is only an area. However, they were special regions that have special properties. Therefore, these special regions are a part of the Indonesian state but they have special characteristics and original arrangements.

The Independence Revolution, marked by the signing of the Charter of Agreement between the United States of the Republic of Indonesia and the Kingdom of the Netherlands, was ended in the Conference of the Bunda Conference. The position of Swapraja Region during this period was stipulated in the 1949 Constitution of the United States of the Republic of Indonesia and the Charter of Approval for Displacement between Indonesia and the Netherlands. Article 3 of the Charter mentions the following points:

1. The United States of the Republic of Indonesia and the Kingdom of the Netherlands recognize and accept that all powers and obligations of the Governor General of Indonesia are, due to the contracts with Swapraja, because the transfer of sovereignty, is transferred to the United States of the Republic of Indonesia, or, if based on the constitutional law, move to a state.

2. Because of the transfer of sovereignty to the The United States of the Republic of Indonesia, all Swaprajas were released due to the law rather than their oath of loyalty to the Majesty the Queen of the Netherlands.

3. The United States of the Republic of Indonesia recognizes the special position of autonomy according to the provisions concerning that matter in its constitution and in the respective regional constitutions, which determine that a free body of the United States of the Republic of Indonesia will decide legal disputes concerning the position of swapraja.

In the 1949 Constitution, the existence of special region is also guaranteed and maintained, namely through the provisions of Articles 64-67. Although the mention is different, the meaning is still the former zelfbesturende landschappen area, which is guaranteed a special position in the 1949 Constitution that existing swapraja areas cannot be erased or scaled down if they do not want to. 
The 1950 Constitution does not mention a term for special region. However, like the 1949 Constitution, it regulates the position of the swapraja region. These regional autonomy arrangements are regulated in Articles 132-133. The UUDS 1950 also regulates the position of autonomous regions governed by laws and the form of government structure must pay attention to the democratic basis that applies in the system of government of the state. In line with the rules in the 1949 Constitution, the 1950 Constitution expressly guarantees that autonomous regions cannot be erased or scaled back against the will of the region. Thus, the formulation of special regions in the 1945 Constitution, 1949 Constitution, and the 1950 Constitution, although using different terms, refer to the same entities. During the Dutch colonial period, it was called zelfbesturende landschappen or special regions. During the era of the 1950 Constitution, based on the prevailing laws and regulations, the Special Region and/or Swapraja Regions, which still existed and were recognized are $^{38}$

1. one special region of provincial level (Yogyakarta);

2. three special regions of regency level (in Kalimantan); and

3. 127 swapraja areas (landschaap) (12 in Kalimantan, 56 in Sunda Kecil, 56 in Sulawesi, and 3 in Maluku).

Although experts have stated that what is meant by special regions are swapraja areas, there are still many questions that arise related to special regions in discussing changes to the 1945 Constitution. Related to the status of special region, in a hearing between the Ad Hoc Committee of the People Consultative Assembly (MPR-Majelis Permusyawaratan Rakyat) and the Indonesian Academy of Sciences (AIPI-Akademi Ilmu Pengetahuan Indonesia), Diana Fauziah Arifin, who represented the AIPI stated ${ }^{39}$ that specifically regarding regional government, she focused on the word's rights of origin and special nature. She questioned explanation of special regions, how one region can be called special, what are the indicators, is it just a struggle, or is it because of the resultant, or others.

It is not surprising that the opinion of Ali Hardi Kiaidemak from the Faction of United Development (FPP-Fraksi Persatuan Pembangunan) also suggested the need to look at original rights in special regions. This needs to be noted because

38 Ibid., pp. 256-257. The Special Region of West Kalimantan is integrated with other parts of Kalimantan into a Kalimantan Province based on the Government Regulation of RIS Number 21 of 1950 on the Formation of Provinces.

39 Mahkamah Konstitusi RI, Naskah Komprehensif Perubahan UUD Negara Republik Indonesia Tahun 1945, Buku IV Kekuasaan Pemerintahan Negara Jilid 2, Jakarta: Sekretariat Jenderal dan Kepaniteraan Mahkamah Konstitusi, 2008, p. 138. 
understanding of the origins and special regions also in practice has also developed that is not in tune to hinder problems in the future. ${ }^{40}$

In the Second Amendment to the 1945 Constitution, the administration of regional government is also one of the points of discussion in the amendment to the 1945 Constitution. Of the 11 factions in the MPR, only seven of them provided formulations for the Article 18. The Factions of Armed Forces and Police (TNI/Polri) did not propose changes but the accommodated the other factions' proposals. ${ }^{41}$

Soedirjato from the Group of Regional Representatives Faction emphasized that the special area must be recognized and seen the origin and history of the area concerned. Not all regions can be said or call themselves special if they do not have a historical background or origins that were recognized before or during Indonesian independence. ${ }^{42}$

The factions that proposed changes to Article 18 of the 1945 Constitution regarding the special regions are as follows:

1. The PDIP Faction proposed Article 18, Paragraph (5) ${ }^{43}$, to be reads, "Rights of origin in special areas including desa, negeri, dusun, marga, nagari, and huta are respected by the state, the implementation of which is regulated by law."

2. The Golkar Party Faction proposed Article 18, Paragraph (3) ${ }^{44}$, to be reads, "The state recognizes customary and territorial law communities to have their own governments based on rights, origins in specific and special regions governed by law."

3. The Reform Faction proposed Article 18, Paragraph $(2)^{45}$, to be reads, "The division of the Indonesian territory into provinces, regencies, and cities is an integration of regional potential and diversity, special rights of origin, special nature as an effort to maintain integration of the nation in the territory of the Republic of Indonesia."

4. The PBB Faction proposed Article 18, Paragraph $(1)^{46}$, to be reads, "The division of Indonesian regions into large and small regions, with the form of government structure, is determined by law, by looking at and observing the basis for deliberation in the system of state government, and the rights the rights of origin in special regions."

In a debate, Hobbes Sinaga of the PDIP proposed a division of arrangements between the customary law territorial community and certain autonomous regions that received a special title. ${ }^{47}$ The proposed separation of customary law territorial

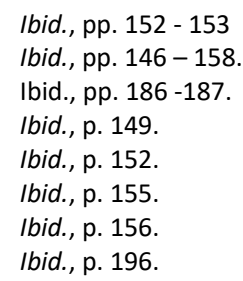


communities from the arrangement of special regions also received support from the PBB. Hamdan Zoelva of the PBB stated that nagari were not included in special regions. ${ }^{48}$ Taufiequrrachman Ruki also confirmed the separation between special regions and adat areas. ${ }^{49}$ Furthermore, Hobbes Sinaga proposed the separation between special regions such as Yogyakarta and regions that have specificities such as Aceh and Papua. ${ }^{50}$ Ali Masykur Musa, as chair of the meeting, stressed that special regions must exist because it is part of the nation's history. ${ }^{51}$ Hatta Mustofa from the Golkar Party Faction stated that ${ }^{52}$ in the constitution, the Special Region of Yogyakarta is special because of its origin and history. The Special Region of Jakarta is also special since its specificity of being the capital. These must be recognized. the Aceh Special Region would become a special area, together with Irian. They must be acknowledged because of the wishes of the people.

These proposals and opinions are then summarized in the sentence, "The State shall recognize and respect entities of regional administration that possess a specificity or a distinctiveness" ${ }^{53}$ In another meeting, it was rearranged into "The State shall recognize and respect entities of regional administration that possess a specificity or a distinctiveness that are to be regulated by law". ${ }^{54}$ Hamdan Zoelva of the PFF Faction expressed his concern because this could lead to many special and specific regions. ${ }^{55}$ This concern was also resonated by Soedijarto of the Group of Regional Representatives Faction that no precedent should be held which eventually all intended to have a special area. ${ }^{56}$

These worries began with the plan for the formulation of Article 18B, Paragraph (1). ${ }^{57}$ Bagir Manan, an expert invited to the meeting on August 13, 2000, delivered his commentary related to the special region that ${ }^{58}$ it is the unity of the government formed by the Netherlands, which is allowed to run the government based on customary law, for example, is the self bestuuren landschapen. That covers the sultanates or the swapraja. They are interpreted as special. Actually, the term special is not because they are really special but in that particular sense so

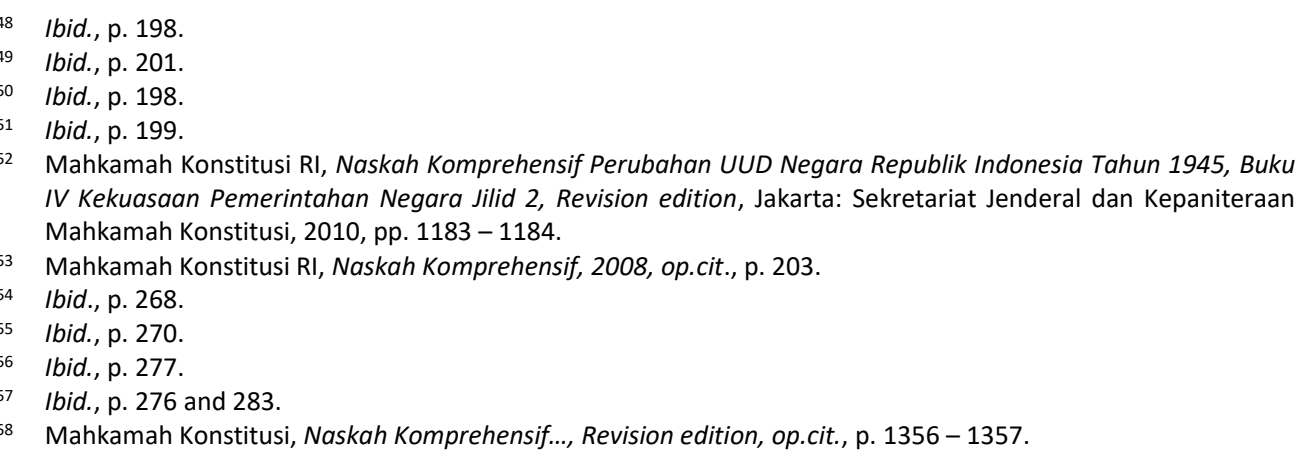


that there are two special things. There are two specialties in the sense of a government unit formed by the Netherlands or recognized by the Netherlands because of an agreement, for example contracts of long or short agreements, then there is one original institution that already exists.

Slamet Effendy Yusuf of the Golkar Party Faction proposed the formulation of Article 18B, Paragraph (1), to be "the State recognizes, respects, and develops special or specific government units that are regulated by law". ${ }^{59}$ Harun Kamil of the Faction of the Group of Envoys, opposed this formulation by asking that phrase "develops" be eliminated so that no more special regions were added. ${ }^{60}$ T.M. Nurlif of the Golkar Party Faction ${ }^{61}$ perfected the formulation, which was finally ratified as the current Article 18B paragraph (1): "The State shall recognize and respect entities of regional administration that possess a specificity or a distinctiveness that are to be regulated by law". The clearest explanation of the position of special region as a continuation of the swapraja area, which was once a zelfbesturende landschappen, can be obtained from the government's statement on the Special Privileges Bill of the Yogyakarta Special Region Province. ${ }^{62}$

The government views the determination of the Indonesian government to recognize the privileges of Yogyakarta by the Law Number 3 of 1950 should be understood as a tribute to the sincerity and commitment of Yogyakarta to integrate with Indonesia, rather than grant of privileges by national political authorities. From a juridical point of view, the Yogyakarta privilege can be referred to the mandate of Sri Paduka Ingkang Sinuwun Kanjeng Sultan and the mandate of Sri Paduka Kanjeng Gusti Prince Adipati Ario Paku Alam, which states that the status of Yogyakarta has changed from a Zelfbesturende Landschappen or Swapraja area to a special area within the Unitary State of the Republic of Indonesia. We can explore even more explicit statements in the 1949 Constitution and the 1945 Constitution.

By referring to the debate that took place in the MPR and also the government's statement related to the Yogyakarta Privileges Bill, the understanding of special region stipulated in Article 18B, Paragraph (1), of the 1945 Constitution still refers to the definition of the swapraja region, which in the Dutch East Indies era was called Zelfbestuurende Landschappen. The meaning of the Special Region based on the Article 18B, Paragraph (1), of the 1945 Constitution is still in harmony with the intention of the Article 18 of the 1945 Constitution, Articles 64-67 of the RIS Constitution, and Articles 132-133 of the 1950 Constitution. Therefore, the meaning of the Special Region is an autonomous region, which is recognized and formed by law. In other words, a special region is

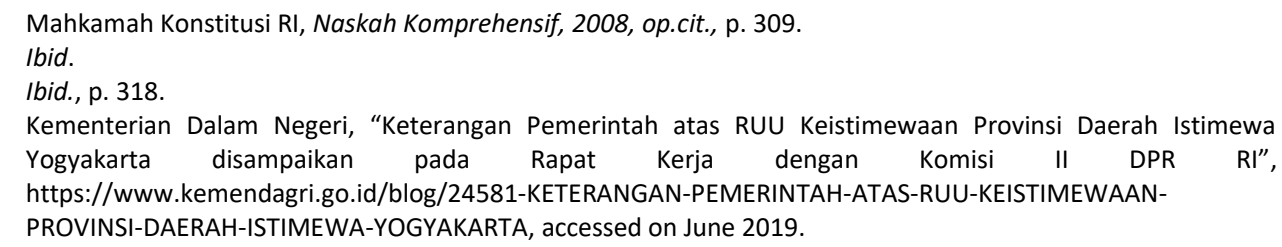


an original unit of an existing institution. Then, the recognition and respect for that special region is based on a law made based on the political will of the government and the parliament's proposal as a regional representation.

\section{B. Status of Special Government Areas}

On the provisions of Articles 18A and 18B, Jimly Asshiddiqie believes that the form of a unitary state has become more dynamic. ${ }^{63}$ First, it is possible to make arrangements that are federalist in the relationship between the central and regional governments. Secondly, in the dynamics of the relationship between the center and the regions, it is also possible to develop a pluralistic autonomy policy, in the sense that for each region different autonomy patterns can be applied.

Not surprisingly, after the amendment to the 1945 Constitution, there were requests from eight regions to obtain the status based on the provisions of Article 18B, Paragraph (1). They are Bali, Surakarta, Tidore, Batam, Parahyangan, East Kalimantan, Riau, and North Sumatra. ${ }^{64}$ The Ministry of Home Affairs has rejected the request because the regions that submitted the proposal did not require special status in issuing policies or handling local dynamics. ${ }^{65}$

However, in the dynamics of local politics, since the formation of the Indonesian Palaces Communication Forum (FKKKI-Forum Komunikasi KeratonKeraton Indonesia), the descendants of Kings and Sultans began to re-consolidate themselves as relatively independent political forces. Beginning with the Keraton Nusantara Festival 1995 in Surakarta, at the Keraton Nusantara Festival III 2002 in East Kalimantan, kings and sultans began to declare their goals to prevent ethnic conflict in their royal territories and reclaim royal lands that become mining concession areas. ${ }^{66}$ During the meeting, the Sultan of Ternate made a statement agreed upon by the rulers of the palaces. ${ }^{67}$

"Kami para sultan dan raja memiliki konsesi atas hutan, tambang, dan lain sebagainya karena semua itu adalah hak tradisional kami. Sekarang setelah merdeka, hak-hak para sultan secara ironis telah dirampok habis. Para sultan dimiskinkan, sementara konglomerat bertambah kaya... Saat kami kembali ke rumah masing-masing, kami akan berjuang menuntut yang telah dirampas oleh pemerintah."

63 Jimly Asshiddiqie, Konstitusi \& Konstitusionalisme Indonesia, Jakarta: Konstitusi Press, 2004, p. 275.

64 Kukuh Setiyono, "Daerah Otonomi Khusus Takkan Bertambah", https://www.gatra.com/detail/news/394902Daerah-Otonomi-Khusus-Tak-Akan-Ditambah, accessed on June 2019.

65 Ibid.

66 Jamie S. Davidson, et.al., Adat dalam Politik Indonesia, Jakarta: Yayasan Pustaka Obor Indonesia, 2010, p. 23.

67 Gerry van Klinken, Kembalinya Para Sultan: Pentas Gerakan Komunitarian dalam Politik Lokal, in Jamie S. Davidson, et. al., ibid., p. 178. 
In the Keraton Nusantara Festival 2017 in Cirebon, the kings and the sultans gave seven recommendations to the government. One of which was the importance of the role of kings and sultans to be involved in the Regional Leadership Coordination Forum because the position of the sultans and kings as cultural leaders and guardians of the Unitary State of the Republic of Indonesia. ${ }^{68}$

The efforts to restore the status of special regions were also carried out by the Surakarta Palace Family through the Constitutional Court. This legal effort does not try to form a new Special Region but to restore the status of a special region that was once frozen by the government. ${ }^{69}$ However, this legal effort temporarily failed because the Constitutional Court stated that the request was not accepted because of problems with the legal position of the applicants..$^{70}$ If we pay attention to the mandate of Article 18B, the state recognizes, respects, and develops native, specific, or special government units. There is a mandate for the state to recognize, to respect and to develop native government units and specific or special governments. There is no prohibition for the state to develop new special regional government units, the development of special regions can be carried out by the state, in this case by the government, the DPR, and the DPD proposal to form the Law. The formation of new special regions, both at the provincial and regency/city levels can be realized as long as it preserves culture, customary law, customary development of state administration. Recognition, respect, and development of cultural values, custom and customary law constitutes legal service as the order of values that grows and develops in Indonesia. Therefore, developing the status of a special region does not actually conflict with the law. Instead, it becomes a complement to national law.

In fact, the meaning and status of special regional government in the 1945 Constitution is still not clearly implemented in the norms of regional government laws. The question is whether or not the legislators not willing to elaborate the norms of the NRI Constitution into the law. The status of special regional government seems to contain uncertainty as to implement the norm. Article 18B, Paragraph (1), is the only provision in the Regional Government chapter, which uses the phrase government unit to regulate the Special Region.

In its history, Indonesia has had special regional arrangements at various levels of government. Article 1, Paragraph (2), of the Law Number 22 of 1948 stipulates that Special Region can be determined at the provincial, city/regency, and even

68 Niken Widya Yunita, "Sultan dan Raja se Indonesia Minta 7 Hal ini kepada Jokowi", https://news.detik.com/berita/d-3651093/sultan--raja-se-indonesia-minta-7-p.-ini-kepada-jokowi, accessed on June 2019.

69 Farid Assifa (ed.), "Keraton Surakarta Gugat Kembalikan Status DI", https://nasional.kompas.com/read/2012/11/14/21422415/Keraton.Surakarta.Gugat.Kembalikan.Status.DI, accessed on June 2019.

70 Bilal Ramadhan, "MK Tolak Gugatan Ahli Waris Keraton Surakarta", https://nasional.republika.co.id/berita/nasional/hukum/n33gea/mk-tolak-gugatan-ahli-waris-keratonsurakarta, accessed on June 2019. 
village level. Article 1, Paragraph (2), of the Law Number 1 of 1957 states that Special Region can be equated with Level I Region, Level II Region, and Level III Region. Based on the Law Number 1 of 1957, it can be seen that the special regions that still exist at that time are Yogyakarta and Special Regions of Regency Level in Kalimantan.

In discussing the Amendment to the 1945 Constitution, particularly related to Article 18B, Paragraph (1), the formulators did not want the addition of Specific and Special Regions. It is not known clearly, what the reasons are. However, in terms of legal politics, the government has long carried out the elimination of special regions based on autonomous regions. Even the Law Number 5 of 1974 explicitly states that as far as possible the autonomous regions in Indonesia are uniformed and even the Article 88, Paragraph (2) (a), presuppose the position of Special Region of Yogyakarta in the future will be abolished.

The Article 18B, Paragraph (1), of the 1945 Constitution contains the principle of the recognition of the State of regional government that is specific or special in nature. This provision supports the existence of various specific or special government units (either at provincial, regency or city, or at village levels). ${ }^{71}$ In line with this, Jimly Asshiddiqie also stated that what is meant as a regional government unit is a provincial regional government unit, a regency/city regional government unit, or a special and special village government. ${ }^{72}$ The National Legal Development Agency mentions that the 1945 Constitution does not regulate the formation or division of regions within Article 18B. ${ }^{73}$

Therefore, the status of special region as mandated by Article 18B, Paragraph (1), of the 1945 Constitution is dynamic in the sense that the constitution enables the formation of new special regions as long as it is the will of the President and the DPR to approve the formation of special regions the new one. In addition, local government units for special regions are not limited to the scope of provincial areas but special regions can be formed within the scope of cities/regencies and even villages.

\section{Conclusion}

The special regional government as referred to in Article 18B, Paragraph (1), of the 1945 Constitution must be seen from the historical approach. It origins from

\footnotetext{
71 Rusdianto Sesung, Hukum Otonomi Daerah: Negara Kesatuan, Daerah Istimewa, dan Daerah Otonomi Khusus, Bandung: Refika Aditama, 2013, p. 54.

72 Jimly Asshiddiqie, Konsolidasi Naskah UUD 1945 Setelah Perubahan Keempat, Jakarta: Pusat Studi HTN FH UI, 2002, p. 24.

73 Badan Pembinaan Hukum Nasional, Pengkajian Hukum Tentang Pemekaran dan Penggabungan Daerah, Jakarta: BPHN, 2009, p. 82.
} 
kingdoms/sultanates (swaprajas) which, at the time, was regulated through a political contract between local rulers and the Government of the Dutch East that Indies made formal in zelfbestuurregelen 1938. They were known as Zelfbestuur Landschappen. During the Japanese occupation, the special area was called Kooti.

The term special or autonomous region after Indonesian independence does not mean that the area is unique. However, it has a special meaning in the sense of a government unit formed by the Netherlands or recognized by the Netherlands because there was an agreement, in the forms of long or short contract, and as an original institution that already existed. One of the characteristics of a special region is an area where the position of regional head comes from the descendants of the royal/sultanate family with the system law-based government, such as the Special Region of Yogyakarta.

Based on the history of the constitution, the special regions are regulated in the pre-amendment of 1945 Constitution, the 1949 RIS Constitution, and the PostAmendments 1945 Constitution. However, the 1950 Constitution clearly provides norms of meaning regarding special regions. The Law Number 9 of 2015, in conjunction with the Law Number 23 of 2014 on Regional Government, does not regulate special regions implicitly. Nevertheless, this Law provides references to other laws. One of them is the Law Number 13 of 2012 on the Yogyakarta Special Region Privileges.

The status of special region, as mandated by Article 18B, Paragraph (1), is dynamic. It means, even though the changes to the 1945 Constitution of the Republic of Indonesia does not lead to the addition of a special region, the legal norm does not prohibit the development of new special local government units at any levels, as long as they preserve culture, customary law, and constitutional development. Recognition, respect, and development of cultural values and customary law, as long as it does not conflict with the 1945 Constitution and other laws, complements the formation of national law. Therefore, the DPR, the DPD, and the current President need to study the formation of regional privileges because the formation of special regional units is not limited to the scope of regencies, cities, and even villages.

\section{References}

\section{Books}

Abdul Gaffar Karim, et.al., Kompleksitas Persoalan Otonomi Daerah di Indonesia, Jurusan IImu Pemerintahan FISIPOL UGM kerjasama dengan Pustaka Pelajar, Yogyakarta, 2006.

Badan Pembinaan Hukum Nasional, Pengkajian Hukum Tentang Pemekaran dan Penggabungan Daerah, BPHN, Jakarta, 2009.

Bagir Manan, Lembaga Kepresidenan, Jakarta, FH UI Press, Jakarta, 2003.

Bayu Surianingrat, Sejarah Pemerintahan di Indonesia: Babak Hindia Belanda dan Jepang, Dewaruci Press, Jakarta, 1981. 
C.F. Strong, Konstitusi-Konstitusi Politik Modern: Studi Perbandingan Tentang Sejarah dan Bentuk, Translated by Derta Sri Widowatie, Nusamedia, Bandung, 2018.

Cassese, Antonio, Self Determination of Peoples: A Legal reappraisal, Cambridge University Press, Cambridge, 1995.

G.J. Wolhoff, Pengantar Ilmu Hukum Tata Negara Republik Indonesia, Timun Mas, Jakarta, 1960.

Hannikainen, Laura, Self Determination and Autonomy in International Law, in Markku Suksi, Autonomy: Application and Implication, Kluwer Law International, Finland, 1997.

Heintze, Hans-Joachim, On the Legal Understanding of Autonomy, in Markku Suksi, Autonomy: Application and Implication, Kluwer Law International, Finland, 1997.

Jamie S. Davidson, et.al., Adat dalam Politik Indonesia, Yayasan Pustaka Obor Indonesia, Jakarta, 2010.

Jimly Asshiddiqie, Konsolidasi Naskah UUD 1945 Setelah Perubahan Keempat, Pusat Studi HTN FH UI, Jakarta, 2002.

Jimly Asshiddiqie, Konstitusi \& Konstitusionalisme Indonesia, Konstitusi Press, Jakarta, 2004.

Jimly Asshiddiqie, Pokok Pokok Hukum Tata Negara Indonesia Pasca Reformasi, $2^{\text {nd }}$ edition, Jakarta: BIP Gramedia, Jakarta, 2008.

Logemann, J.H.A, Het Staatsrecht van Indonesie, Badan Penerbit Gadjah Mada, Yogyakarta.

Lukman Hakim, Filosofi Kewenangan Organ Lembaga Daerah: Perspektif Teori Otonomi \& Penyelenggaraan Pemerintah Negara Hukum dan Kesatuan, Setara Press, Malang, 2012.

Mahkamah Konstitusi RI, Naskah Komprehensif Perubahan UUD Negara Republik Indonesia Tahun 1945, Buku IV Kekuasaan Pemerintahan Negara Jilid 2, Sekretariat Jenderal dan Kepaniteraan Mahkamah Konstitusi, Jakarta, 2008.

Mahkamah Konstitusi RI, Naskah Komprehensif Perubahan UUD Negara Republik Indonesia Tahun 1945, Buku IV Kekuasaan Pemerintahan Negara Jilid 2, Revision edition, Sekretariat Jenderal dan Kepaniteraan Mahkamah Konstitusi, Jakarta, 2010.

Ni'matul Huda, Hukum Pemerintahan Daerah, Bandung: Nusa Media, Bandung, 2010.

R Soepomo, Sistem Hukum di Indonesia Sebelum Perang Dunia II, Pradnya Paramita, Jakarta, 1991.

R. Tresna, Peradilan di Indonesia Dari Abad ke Abad, Pradnya Paramita, Jakarta, 1978. 
Rusdianto Sesung, Hukum Otonomi Daerah: Negara Kesatuan, Daerah Istimewa, dan Daerah Otonomi Khusus, Refika Aditama, Bandung, 2013.

Saafroedin Bahar, et.al., Risalah Sidang Badan Penyelidik Usaha - usaha Persiapan Kemerdekaan Indonesia (BPUPKI) - Panitia Persiapan Kemerdekaan Indonesia (PPKI) 29 Mei 1945-19 Agustus 1945, Sekretariat Negara Republik Indonesia, Jakarta, 1992.

Soejono Soekanto, Pengantar Sejarah Hukum, Alumni, Bandung, 1986.

The Liang Gie, Pertumbuhan Pemerintahan Daerah di Negara Republik Indonesia Jilid I, $2^{\text {nd }}$ edition, Liberty, Yogyakarta, 1993.

Usep Ranawidjaja, Swapradja: Sekarang dan Di Hari Kemudian, Djambatan, Jakarta, 1955.

Weller, Marc, Katherine Nobbs, Asymmetric Autonomy and the Settlement of Ethnic Conflics, University of Pennsylvania Press, Pennsylvania, 2010.

\section{Other Documents}

Bilal Ramadhan, "MK Tolak Gugatan Ahli Waris Keraton Surakarta", https://nasional.republika.co.id/berita/nasional/hukum/n33gea/mk-tolakgugatan-ahli-waris-keraton-surakarta, accessed on June 2019.

Farram, Steven Glen, "From Timor Koepang to Timor NTT: A Political History of West Timor, 1901-1967", Thesis for the degree of Doctor of Philosophy of the Northern Territory University, p. $10 \quad-\quad 11$, https://espace.cdu.edu.au/eserv/cdu:6450/Thesis_CDU_6450_Farram_S.pdf, accessed on May 2019.

Henley, David, "Nationalism and Regionalism in Colonial Indonesia: The Case of Minahasa", JSTOR, No. 55, 1993, p. 93, https://www.jstor.org/stable/3351088, accessed on May 2019.

John Mcgarry, "Asymmetry in Federations, Federacies and Unitary States", Ethnopolitics, Vol. 6, No. 1, 2007.

Kementerian Dalam Negeri, "Keterangan Pemerintah atas RUU Keistimewaan Provinsi Daerah Istimewa Yogyakarta disampaikan pada Rapat Kerja dengan Komisi II DPR RI", https://www.kemendagri.go.id/blog/24581-KETERANGANPEMERINTAH-ATAS-RUU-KEISTIMEWAAN-PROVINSI-DAERAH-ISTIMEWAYOGYAKARTA, accessed on June 2019.

Kukuh Setiyono, "Daerah Otonomi Khusus Takkan Bertambah", https://www.gatra.com/detail/news/394902-Daerah-Otonomi-Khusus-TakAkan-Ditambah, accessed on June 2019.

Meriam-Webster, "Vassal State", https://www.merriamwebster.com/dictionary/vassal\%20state, accessed on May 2019.

Niken Widya Yunita, "Sultan dan Raja se Indonesia Minta 7 Hal ini kepada Jokowi", https://news.detik.com/berita/d-3651093/sultan--raja-se-indonesia-minta-7p.-ini-kepada-jokowi, accessed on June 2019. Farid Assifa (ed.), "Keraton Surakarta Gugat Kembalikan Dtatus ", 
https://nasional.kompas.com/read/2012/11/14/21422415/Keraton.Surakarta.

Gugat.Kembalikan.Status.DI, accessed on June 2019.

\section{Legal Documents}

1945 Constitution of the Republic of Indonesia [Undang-Undang Dasar Negara Republik Indonesia Tahun 1945]

General Government Commissariat for Borneo and the Grote Oost, Self-governing regulation 1938 With Explanation [Algemeen Regering-Commissariaat voor Borneo en de Grote Oost, Zelfbestuuregelen 1938 Met Toelichting]

The Declaration of Director of Domestic Administration, October 5, 1938 [Ma'loemat Directeur Binnenlandsch Bestuur, 5 Oktober 1938] 